УДК $616.073+616.43+616.7$

DOI 10.36910/6775-2313-5352-2021-18-3

${ }^{1}$ Витвицька Л. А. ${ }^{2}$ Дудій П. Ф., ${ }^{2}$ Скрипник Н.В., ${ }^{2}$ Витвицький 3. Я.

${ }^{1}$ Івано-Франківський національний технічний університет нафти і газу

${ }^{2}$ Івано-Франківський національний медичний університет

\title{
УДОСКОНАЛЕНИЙ МЕТОД ТА ПРИСТРІЙ ДЛЯ КОМПЛЕКСНОГО ДОСЛІДЖЕННЯ УРАЖЕНЬ ЩИТОПОДІБНОЇ ЗАЛОЗИ ТА ОКА ЛЮДИНИ
}

\begin{abstract}
Проаналізовано методи діагностики захворювань щитоподібної залози та структур ока. Обгрунтовано доиільність проведення комплексного дослідження на основі ультразвукових методів: кольорового картування, доплерографії та еластографії для встановлення кількісних показників, ще характеризують жорсткість м'яких тканин. Запропоновано конструкиію n'єзоелектричного давача, який забезпечує рівність ширини і товщини променя на кожній із глибин сканування. Обгрунтовано спосіб проведення дослідження.
\end{abstract}

Ключові слова: ультразвукове дослідження, жорсткість тканин, еластографія, щитоподібна залоза, ендокринна офтальмопатія.

Вступ та постановка проблеми.. Ураження ендокринної системи є складною проблемою сучасної медицини, оскільки відіграє провідну роль у структурі захворюваності населення. За даними багатьох науковців, кількість хворих на дану патологію щороку зростає. Серед усіх захворювань увагу привертає дифузний токсичний зоб (далі - ДТЗ), оскільки часто уражає осіб працездатного віку та характеризується розвитком ускладнень, що веде до втрати працездатності, зниження якості життя, інвалідизації. Найчастішим проявом ДТЗ є ураження органу зору (ендокринна офтальмопатія), при цьому найбільших змін зазнають навколоочні м'язи та жирова клітковина, розташована позаду очного яблука (ретробульбарний простір) [1].

Мета роботи. Важливим в діагностиці ендокринної офтальмопатії $є$ розмежування активної та неактивної фази хвороби. У активній фазі запалення відмічається набряк жирової клітковини орбіти та окорухових м'язів, у неактивній фазі - розростання сполучної тканини (фіброз) у цих органах [2]. Оскільки консервативне лікування є можливе тільки в активній фазі, важливим є визначення жорсткості структур орбіти. Ультразвукове дослідження (УЗД) дає можливість візуалізувати структури органу зору. Метод має ряд переваг: висока інформативність, неінвазивність, безболісність, простота виконання і доступність. Класичне УЗД включає В-режим та доплерографію, що допомагають візуалізувати тканини органу зору [3]. Проте, обстеження в даних режимах не дають інформативності про їх жорсткість і унеможливлюють розмежування фаз ендокринної офтальмопатії. Саме тому ставиться задача розроблення додаткового комплексного методу оцінки стану тканин органу зору та щитоподібної залози, який дозволив би визначати їх жорсткість і діагностувати фази захворювання для вибору тактики лікування та контролю перебігу хвороби

Результати роботи. Останнім часом активно розробляються різні способи візуалізації зсувних пружних характеристик біологічних м'яких тканин - так звані способи еластографії, які доповнюють традиційні методи візуалізації (ультразвукові, рентгенівські і ін.). Під поняттям еластографії розуміється вимірювання коефіцієнту пружності м'яких тканин, який залежить від їх стійкості до механічного розтягування/стиснення. Ці методи грунтуються на заданні в тканинах зсувів і на їх дистанційному вимірі тим чи іншим чином. Для візуалізації зсувів використовуються ультразвукові методи. Існує два різних методи еластографії, що використовується для дослідження щитоподібної залози: компресійна еластографія (Strain Elastography (SE), якісний, або напівкількісний метод), в якій використовується сила стиснення від руки дослідника $з$ давачем чи від пульсації сонної артерії (квазістатичний). Існує також кількісний варіант еластографії за допомогою хвиль зсуву (Shear Wave Elastography (SWE)), при цьому давач індукує ультразвуковий імпульс, утворюється поперечна хвиля зсуву, яку й вимірюють. Еластографія зсувної хвилі - кількісний метод оцінки пружності тканин. В основі методу лежить фіксація поперечних пружних хвиль, які поширюються в м'яких і твердих тканинах після впливу ультразвуку. Апарат фіксує 
швидкість поширення зсувних хвиль (визначається прямо пропорційним модулю Юнга модулем зсуву). На відміну від компресійної еластографії, даний метод дозволяє застосувати як високочастотні, так і низькочастотні давачі, що збільшує глибину сканування без втрат точності. Хоча еластографія зсувної хвилі має деякі недоліки: на якість дослідження впливають різні включення, межі тканин, шуми і артефакти. I все ж, даний метод УЗД вважається найбільш ефективним, оскільки дає можливість не тільки визначити жорсткість тканин, але і розрахувати коефіцієнт їх пружності.

Для задання зсувів використовуються різні джерела, наприклад, низькочастотні пульсації, створені серцем і судинами i досить високочастотні зсувні хвилі, які випромінюються взаємодіючими ультразвуковими пучками або одним фокусованим ультразвуковим пучком за рахунок радіаційного тиску. Найчастіше використовується задання вимушених деформацій в глибині тканин (хвильових або квазістатичних) за допомогою поверхневого джерела. Модальність еластографії, що використовує завдання вібраційних деформацій з поверхні і їх ультразвукову візуалізацію, отримала назву «соноеластографії». Найчастіше для візуалізації пружних параметрів тканин використовуються методи, засновані на кореляційній обробці ехографічних зображень деформованих тканин.

Пропонується спосіб ультразвукового дослідження як щитоподібної залози, так i ретробульбарних структур за допомогою мультипараметричного ультразвукового обстеження, при якому використовується сірошкальний В-режим з кольоровим доплерівським картуванням і режим зсувнохвильової еластографії.

Поперечна роздільна здатність УЗ діагностичної системи i, відповідно, якість зображення залежать від ширини УЗ променя. Пропонується використовувати режим динамічного секторного сканування шляхом змінного фокусування ультразвукового променя. Найкращим чином можливості динамічного фокусування забезпечують завдяки застосуванню багатоелементних перетворювачів в давачах електронного лінійного, конвексного і фазованого сканування, а також при механічному скануванню за допомогою кільцевих решіток.

Давач механічного секторного сканування виготовляється 3 плоского п’єзокерамічного диску шляхом розрізання диску на концентричні кільця, число яких зазвичай не менше 5. Кільця закріплені на загальному демпфері і мають загальні погоджуючі шари.

Кожне із кілець електрично з'єднано 3 окремим приймачем. Для випромінювання зондуючого сигналу на кільця подаються електричні імпульси. Якщо вони поступають одночасно, то кільцева решітка майже нічим не відрізняється від плоского суцільного одноелементного перетворювача Якщо ж на кільця подають імпульсні сигнали 3 різним взаємним зсувом в часі, то можна змінювати форму променя. Так, якщо взаємний зсув затримок графічно мають вигляд сферичної поверхні певного радіусу (рисунок 1), то при випроміненні імпульсів окремими кільцями (відповідно в різний час) формується промінь, майже повністю аналогічний променю, що формується сферичним одноелементним перетворювачем з таким же радіусом сферичної поверхні.

На відмінно від давача 3 перемикаючими перетворювачами давач з кільцевою решіткою дозволяє встановити фокус на будь-якій глибині і отримати складене зображення з будь-якою кількістю фокальних зон.

На рисунку 1 зображені розміри променя - ширина $\mathrm{i}$ товщина в зоні фокусу $\mathrm{F}_{1}$ в площині, що проходить через вісь променя перпендикулярно площині сканування [3]. Принципова відмінність кільцевих решіток від всіх інших багатоелементних перетворювачів (лінійних, конвексних і секторних) - рівність ширини і товщини променя на кожній із глибин внаслідок того, що промінь має осесиметричну форму.

Вище йшла мова про формування променя на передачу (випромінюючого променю). Відразу ж після випромінювання зондуючи імпульсів давач переходить в режим прийому ехосигналів. Просторово-виборчі властивості давача визначаються при цьому формою приймального променя. Якщо на прийом використовується той самий перетворювач, то форма приймального променя практично повторює форму передавального променя. В кільцевій решітці для цього в режимі прийому повинні використовуватись ті ж кільця, а ехо-сигнали, ними прийняті, повинні пройти через такі ж за величиною лінії затримки, що і при випромінені (передачі).. Часто в режимі прийому використовуються не всі кільця - особливо при прийомі 3 малих глибин. В цьому випадку приймальний промінь за формою відрізняється від передавального.

๑) Витвицька Л. А., Дудій П. Ф., Скрипник Н. В., Витвицький 3. Я. 


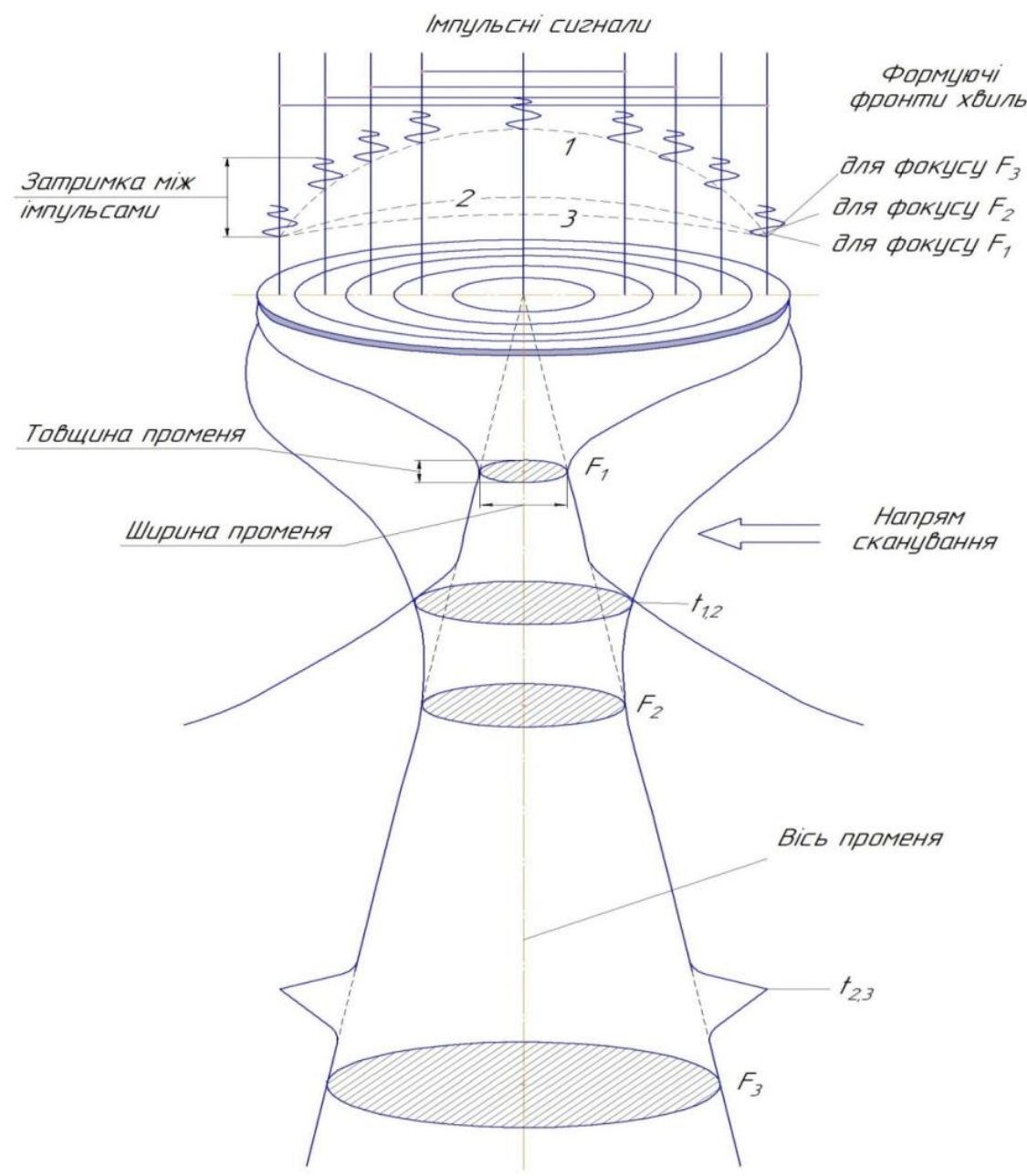

Рисунок 1 - Електронне динамічне фокусування в давачі з кільцевою решіткою. Вигляд складеного УЗ променя

Давач 3 кільцевою решіткою дозволяє встановити фокус на будь-якій глибині і отримати складене зображення з будь-якою кількістю фокальних зон. В багатоелементному перетворювачі можна оперативно змінювати розмір активної частини апертури (поверхні перетворювача, що випромінює і приймає У3 сигнали), підключивши більшу або меншу кількість елементів решітки до приймача або передавача сигналів. Зміна розміру апертури а процесі отримання зображення забезпечує більш однорідне зображення по глибині.

Комплексне дослідження щитоподібної залози та ретробульбарного простору ока проводиться в В-режимі з застосуванням доплерографії з наступним визначенням особливостей розташування, розмірів, ехогенності, ехоструктури щитоподібної залози та ретробульбарних структур, основних доплерометричних показників швидкості потоку крові, індексу резистентності в сонній та очній артеріях та додатковим проведенням зсувнохвильової еластографії залози та ретробульбарної клітковини, окорухових м'язів, зорового нерва із встановленням показників швидкості зсувної хвилі при проходженні через досліджуваний об'єкт в м/с та кольорового еластографічного картування .

Ультразвукове двовимірне, доплерівське дослідження щитоподібної залози та ока із застосуванням зсувнохвильової еластографії проводиться таким чином. Положення пацієнта при обстеженні - лежачи на спині. Обидва ока закриті. Спочатку проводиться дослідження залози, а потім очей. Пацієнт дивиться прямо. При дослідженні очей на простерилізований давач наносять бар'єрний чохол, велику кількість гелю та прикладають безпосередньо до повіки, не створюючи компресії. Глибину проникнення коригують до 4 см, фокус встановлюють на 2,5 см, механічний індекс - до 0,23 . Давач розміщують в поперечній позиції, направивши його мітку до правої сторони пацієнта. Нахиляють давач «зверху вниз» по площині

๑ Витвицька Л. А., Дудій П. Ф., Скрипник Н. В., Витвицький 3. Я. 
очного яблука, щоб візуалізувати усі структури. Далі повертають давач на $90^{\circ}$ так, щоб мітка була направлена до тім'яної частини голови пацієнта. Давач нахиляють вправо та вліво. В Врежимі візуалізують очне яблуко. Після оцінки очного яблука проводять оцінку стану ретробульбарних структур. Давач переводять в поперечну позицію, направивши мітку давача до правої сторони пацієнта і в В-режимі візуалізують окорухові м'язи, зоровий нерв та ретробульбарну клітковину навколо нього. Оцінюють їх локалізацію, ехогенність, ехоструктуру. Вимірюють поперечний розмір зорового нерва. Вимірювання проводять на відстані 3 мм вниз від очного яблука. Надалі для вивчення васкуляризації ока при максимально низькому рівні фільтра та оптимальному коефіцієнті підсилення за допомогою кольорового доплерівського картування візуалізують очну артерію. Коли очна артерія візуалізована, вимірюють швидкість кровоплину, пульсаційний індекс та індекс резистентності за допомогою імпульснохвильової доплерографії. Зону ретробульбарних структур поміщують всередину рамки для встановлення якісних показників жорсткості. Проводять кольорове картування, де більш м'які тканини відображаються зеленим та голубим кольорами, а жорсткі - червоним. Для оцінки кількісного показника жорсткості на візуалізовану в В-реживі ділянку ретробульбарної клітковини та окорухового м'яза встановлюють вікно еластометрії і визначають швидкість проходження зсувної хвилі через обстежувану структуру в м/сек. Заміри проводять в трьох точках, з яких визначають середне значення. Далі розміщують вікно та визначають показник швидкості проходження зсувної хвилі на трьох рівнях зорового нерва: біля виходу із очного яблука, посередині зорового нерва та на дистальному відділі очноямкової частини нерва. Визначають середнє значення із трьох ділянок. Відмічають та вносять у протокол дані про розміри, ехогенність, та структуру ретробульбарних структур, доплерометричні показники кровоплину в сонній та очній артерії, показники кольорового картування та швидкості проходження зсувної хвилі в м/с в зоровому нерві, ретробульбарній клітковині та окорухових м'язах. Аналогічно проводять дослідження на другому оці та вносять результати в протокол обстеження пацієнта.

Висновки Розроблений удосконалений метод комплексного дослідження щитоподібної залози та очей дозволяє встановити взаємозалежність захворювань і визначити ефективність лікування. Ультразвукове дослідження щитоподібної залози та ретробульбарних структур шляхом проведення діагностики в В-режимі з використанням кольорової доплерографії та зсувнохвильової еластографії забезпечує можливість одержання інформації не тільки про розташування, розміри, ехогенність, ехоструктуру, кровопостачання структур, а також про їх жорсткість. Оцінка цих показників підвищує ефективність діагностики захворювань щитоподібної залози та структур орбіти ока, наприклад, ендокринної офтальмопатії та глаукоми.

\section{Література}

1. Белодурина А.Д. Топография и клеточный состав жировой клетчатки глазницы. Ее роль в развитии офтальмопатологии/ А.Д. Белодурина, В.А. Бивалькевич// Вестник совета молодых учёных и специалистов Челябинской области. - 2016. - №3 (14). - Т. 3. - С. 74-75. (365).

2. Паньків В.І. Ендокринна офтальмопатія/ В.І. Паньків// Новини фармації. - 2011. - № 10

3. Синг А.Д. Ультразвуковая диагностика в офтальмологии / Арун Д. Синг, Бренди К. Хейден; пер. с англ. ; под общ. ред. А.Н.Амирова. - М. : МЕДпресс-информ, 2015. - 280 с.

${ }^{1}$ Vytvytska L. A., ${ }^{2}$ Dudiy P. F., ${ }^{2}$ Skrypnyk N. V., ${ }^{2}$ Vytvytsky Z. Ya.

${ }^{1}$ Ivano-Frankivsk National Technical University of Oil and Gas

${ }^{2}$ Ivano-Frankivsk National Medical University

\section{ADVANCED METHOD AND DEVICE FOR COMPREHENSIVE INVESTIGATION OF THYROID GLAND AND EYES}

Methods of diagnosis of diseases of the thyroid gland and eye structures are analyzed. The expediency of conducting a comprehensive study based on ultrasound methods: color mapping, Doppler and elastography to establish quantitative indicators that characterize the stiffness of soft tissues. The design of a piezoelectric transducer is proposed, which provides equality of beam width and thickness at each of the scan depths. The method of research is substantiated. 
Key words: ultrasound examination, tissue stiffness, elastography, thyroid gland, endocrine ophthalmopathy.

${ }^{1}$ Витвицкая Л. А. ${ }^{2}$ Дудий П. Ф., ${ }^{2}$ Скрипник Н.В., ${ }^{2}$ Витвицький С. Я.

${ }^{1}$ Ивано-Франковский национальный технический университет нефти и газа

${ }^{2}$ Ин-Франковский национальный медицинский университет

\section{УСОВЕРШЕНСТВОВАННЫЙ МЕТОД И УСТРОЙСТВО ДЛЯ КОМПЛЕКСНОГО ИССЛЕДОВАНИЯ ПОРАЖЕНИЯ ЩИТОВИДНОЙ ЖЕЛЕЗЫ И ГЛАЗ ЧЕЛОВЕКА}

Проанализированы методы диагностики заболеваний щитовидной железы и структур глаза. Обоснована иелесообразность проведения комплексного исследования на основе ультразвуковых методов: иветного картирования, допплерографии и эластографии для установления количественных показателей, характеризующих жесткость мягких тканей. Предложена конструкиия пьезоэлектрического датчика, который обеспечивает равенство ширины и толщины луча на каждой из глубин сканирования. Обоснован способ проведения исследования.

Ключевые слова: ультразвуковое исследование, жесткость тканей, эластография, щитовидная железа, эндокринная офтальмопатия. 